\title{
CAPRINE MASTITIS EXPERIMENTALLY INDUCED WITH MYCOPLASMA OVINE/CAPRINE SEROGROUP 11 (2-D)
}

\author{
J. S. RANA, P. P. GUPTA, H. S. BANGA and D. KUMAR \\ Department of Veterinary Pathology, \\ Punjab Agricultural University, Ludhiana - 141 004, India
}

Received May 20, 1992

\begin{abstract}
Rana J. S., P. P. Gupta, H. S. Banga, D. Kumar : Caprine Mastitis Experimentally Induced With Mycoplasma Ovine/Caprine Serogroup 11 (2-D). Acta vet. Brno, 61, 1992: $231-240$.

Right mammary gland of seven lactating goats was inoculated with $1 \mathrm{ml}$ of $\mathrm{Myco}$ plasma ovine/caprine serogroup 11 (M. oc), containing $6 \times 10^{6}$ colony forming units per $1 \mathrm{ml}$ through the teat canal. The infected glands were hot, tender, painful and swollen from the first day post inoculation. The mastitic milk showed characteristic physical changes and marked increase in somatic cell count. Subsequently, there was reduction in gland size and agalactia. The experiment was continued for 35 days, during which one animal was killed at every 5 days interval. Histopathologic examination indicated that the acute phase of the induced mastitis was characterised by vacuolation and degeneration of secretory epithelium with a marked neutrophil and macrophage response. Subsequently, the chronic interstitial mastitis was characterised by lymphocytic infiltration, chronic galactophoritis and extensive fibrosis leading to reduction in glandular parenchyma which was the cause of agalactia in the infected glands. This study confirms the pathogenicity of $M$. oc for the caprine mammary gland and is the first description of the clinico-pathologic features of the experimental caprine mastitis induced by this organism.
\end{abstract}

Goats, Mycoplasma ovine/caprine serogroup 11, mastitis, galactophoritis

Mycoplasma ovine/caprine serogroup $11(M$. oc) was first isolated from spontaneous cases of granular vulvovaginitis in sheep in Australia by Cottew et al. (1974) and subsequently from similar cases in goats in India ( $\mathrm{Tiw}$ an a et al. 1984). This organism has also been isolated from the mammary glands and milk samples from the natural cases of caprine mastitis (Prasad et al. 1984). However, its pathogenicity to the mammary gland and its role in producing mastitis has not been studied experimentally. Therefore, the present work was undertaken to assess the pathogenicity of $M$. oc to the lactating mammary gland and to study the sequential pathological changes. produced in the mammary gland.

\section{Materials and Methods}

\section{Experimental animals}

Seven lactating goats aged 2 to 3 years were kept under observation for 1 week before starting the experiment. They were judged to be healthy and free from sub-clinical mastitis after going through some clinical examinations like testing of their blood and milk samples. The milk samples. were free from bacteria and mycoplasma.

\section{Infectious agents}

Forty-eight hour old culture of $M$. ovine/caprine serogroup 11 (2-D) at 3rd passage level containing. $6 \times 10^{6}$ colony forming units (CFU) $\mathrm{ml}^{-1}$ was used for inoculation in the present study. 


\section{Mode of Infection}

One $\mathrm{ml}$ of this culture was inoculated through the teat canal into the right mammary glands of all the 7 goats. Their left glands were similarly inoculated with $1 \mathrm{ml}$ of sterile mycoplasma broth and they served as control.

\section{Experimental design}

All the animals were clinically examined daily for development of abnormal changes in the mammary glands, as well as for evidence of mastitis by California and modified Whiteside mastitis tests. The milk yield from both the mammary glands of all the goats was measured daily. Somatic cell count (SCC) of the milk samples collected before and after inoculation was determined and the samples were cultured on mycoplasma medium (Banerjee et al. 1979) and blood agar. The experiment was continued for 35 days and one goat was killed every 5 th day up to 35 th day post-inoculation (PI). Mammary glands and their lymph nodes were examined grossly and microscopically. For the latter, $5 \mu \mathrm{m}$ thick paraffin sections were stained with haematoxylin and eosin (H. E.).

\section{Results}

The appetite and body temperature of all the 7 experimentally infected goats remained normal throughout the experiment. But, they developed varying degree of mastitis in the right mammary glands from the first day PI. These glands became hot, tender, painful and larger than the left control glands during the first 5 days PI. Thereafter, the size of the infected glands started decreasing and they became very small and more firm as compared to their left counterparts at the end of the experiment. The average volume of milk secreted from the right infected glands dropped sharply from $107.28 \mathrm{ml}$ to $17.28 \mathrm{ml}$ on 5 th day PI (Table 1) while remaining 3 goats developed agalactia in their infected glands from 22nd day PI. The mastitic mammary secretion was yellowish, slightly flocculent and very thick pus-like up to $4-5$ days PI, thereafter it became thin and flocculent. In all the goats, the milk proteins settled down as aggregates leaving a whey-like supernatant fluid on keeping the milk undisturbed. On the other hand, there was no significant change in the colour, consistency and amount of milk drawn from the uninfected left mammary glands of all the goats. The SCC of milk from the infected glands increased markedly from the average basal value of $0.50 \times 10^{6} \mathrm{ml}^{-1}$ to a maximum of $49.59 \times 10^{6} \mathrm{ml}^{-1}$ on 8 th day PI. Thereafter, this count declined gradually but it remained still much higher than the basal value (Table 1). However, the SCC in milk from the uninfected glands remained unaffected.

Mycoplasma were not detected in pre-inoculation milk samples from any goat. $M$. oc was re-isolated from the milk of all the infected glands up to 20 th day PI but it could not be isolated from the milk of left uninfected glands. No bacteria were isolated from the milk of either infected or control glands. Haematological analysis revealed marked leucocytosis with neutrophilia in initial stages and lymphocytosis in later stages (Table 2).

At necropsy, the infected right gland and the supramammary lymph node of the goat killed on 5th day PI were markedly larger than their left counterparts. However, in the goats killed at subsequent intervals, the infected glands were reduced in size but their supramammary lymph nodes remained larger than their left counterparts.

Microscopically, mastitis was seen only in the right infected glands. The goat killed on 5th day PI showed acute, diffuse purulent mastitis characterised by 

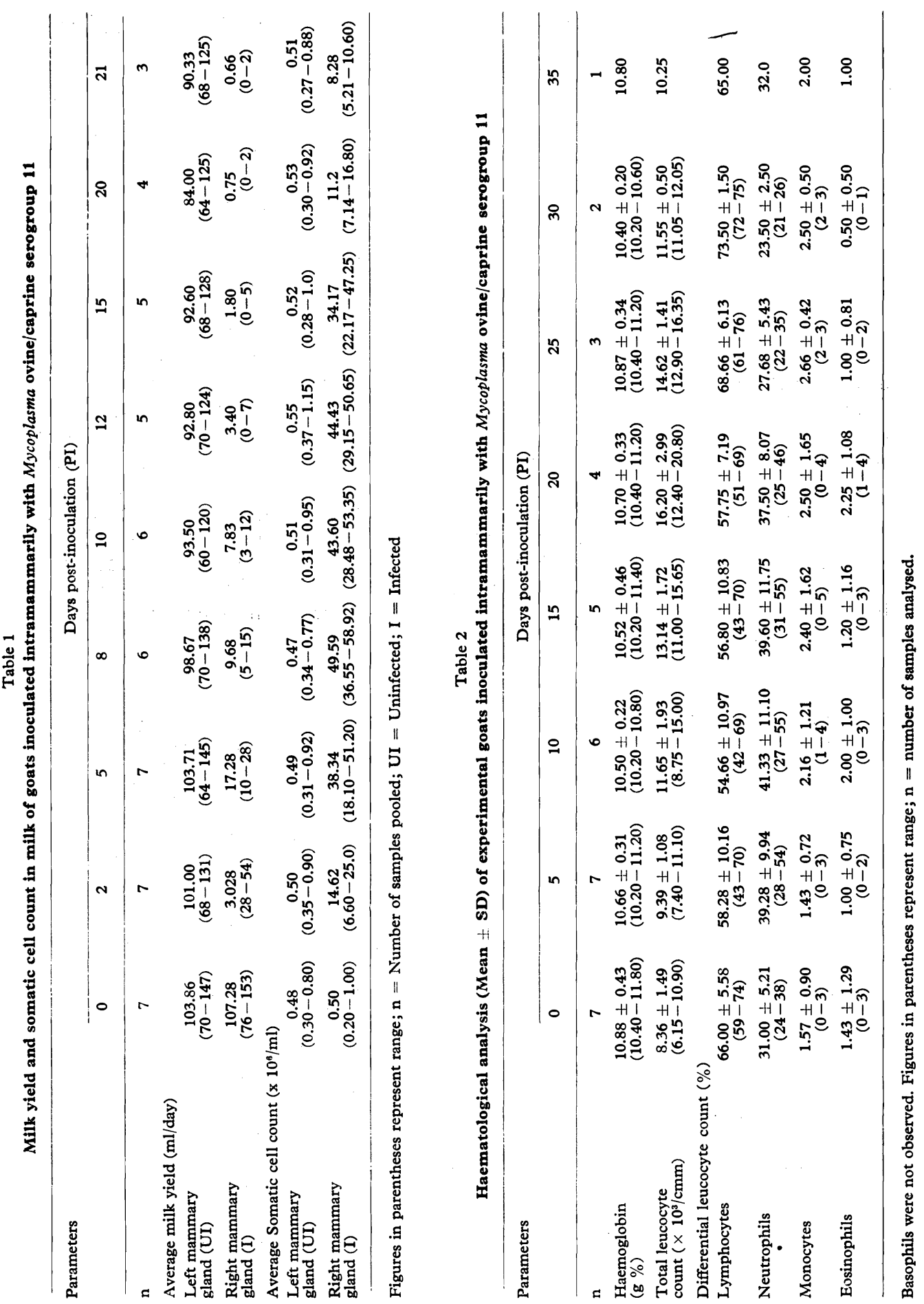
marked infiltration of neutrophils in the lumina of acini (Fig. 1) and milk ducts. There was marked vacuolar degeneration (Fig. 1) and exfoliation of the secretory and the ductal epithelium. The necrotic exudate in the lumina of few acini showed dystrophic calcification and there was begining of formation of laminated calcified corpora amylacea. The acute mastitis subsided with the supervention of chronic mastitis characterised by fibrosis in the interlobular septa leading to their thickening (Fig. 2) and infiltration of lymphocytes and macrophages in the interacinar interstitial tissue on 10th day PI. This resulted in decrease in the size of acini. On 15th day PI, severe infiltration of lymphocytes besides few macrophages in the interstitial tissue resulted in complete replacement of most of the acini (Fig. 3) and marked fibrosis resulted in thickening of interlobular septa (Fig. 4). There was increased formation of calcified corpora amylacea in the acini at this stage (Fig. 5). The milk ducts showed chronic galactophoritis. On 20th day PI, the infected gland revealed more chronic mastitis than that seen at earlier stages. Extensive interlobular and interacinar fibrosis resulted in pseudolobulation and atrophy of secretory lobules. At places, there was cystic dilatation of a group of acini due to fibrosis around them (Fig. 6). Lymphoid aggregates were seen adjacent to some lactiferous ducts. In the infected glands of the goats killed on 25th, 30th and 35th day PI, the microscopic changes were similar but more chronic than those seen on 20th day PI. Most of the glandular parenchyma was replaced by fibrous tissue and very small lobules could be seen as islands in an ocean of fibrous tissue. At 35th day PI, severe galactophoritis characterised by periductal fibrosis and stratified squamous metaplasia of the ductal epithelium was observed (Fig. 7). The right supramammary lymph nodes of all the

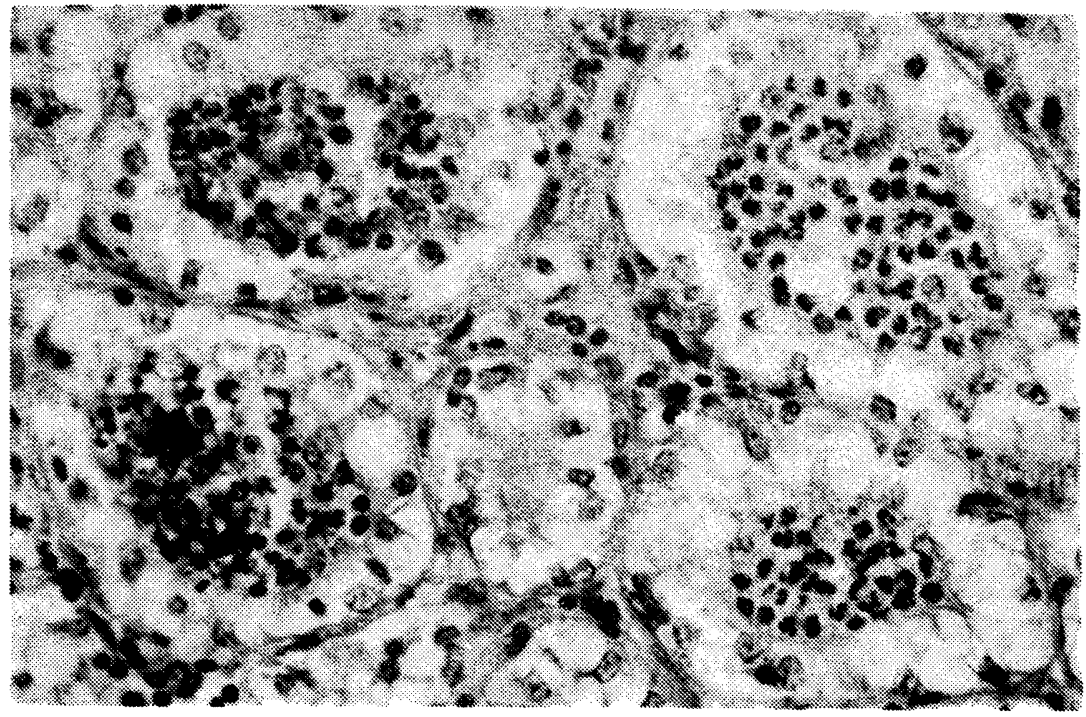

Fig. 1. Five days post-inoculation; acute, diffuse purulent mastitis with marked neutrophil infiltration in the lumina of acini of the infected gland. Also note marked vacuolar degeneration in the acinar epithelial cells. H. E. X 300 . 


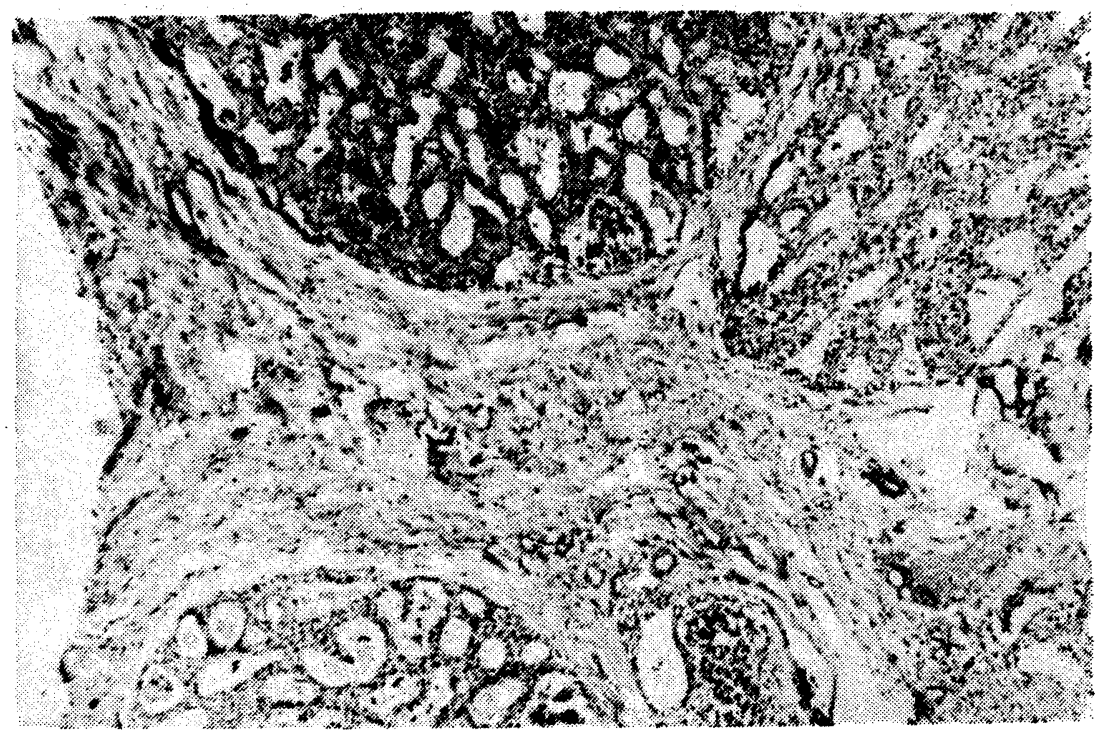

Fig. 2. Ten days post-inoculation; chronic mastitis with fibrosis in the interlobular septa leading to their thickening. H. E. X 75 .

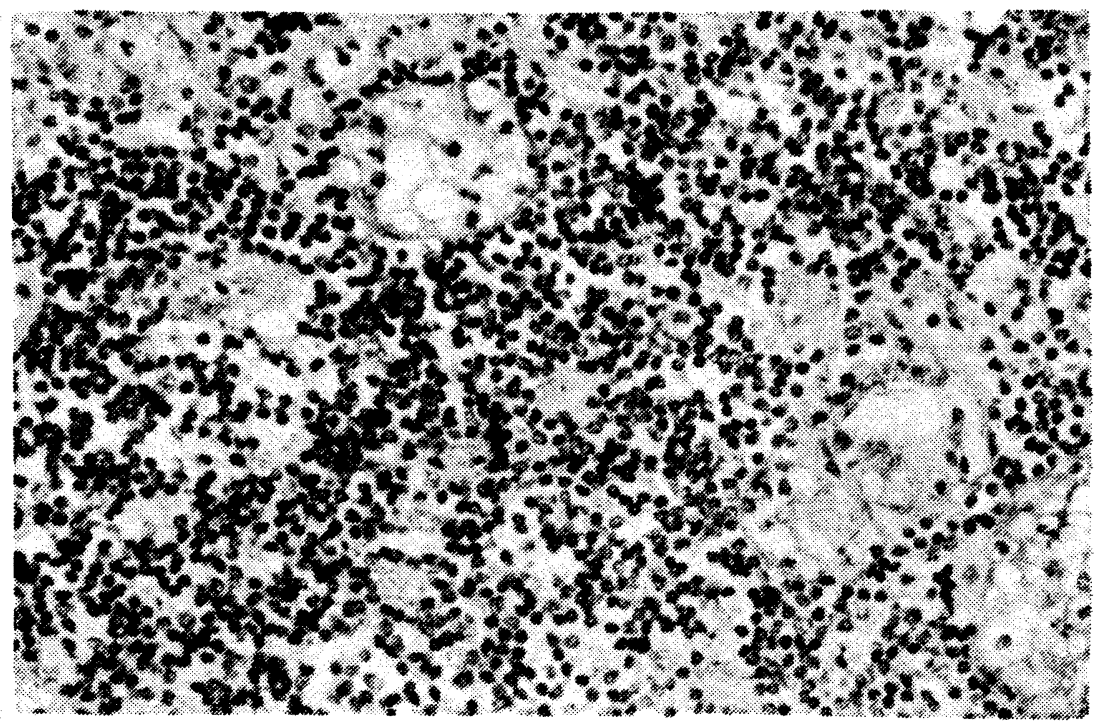

Fig. 3. Fifteen days post-inoculation; marked lymphocytic infiltration replacing most of the acini H. E. X 300 . 


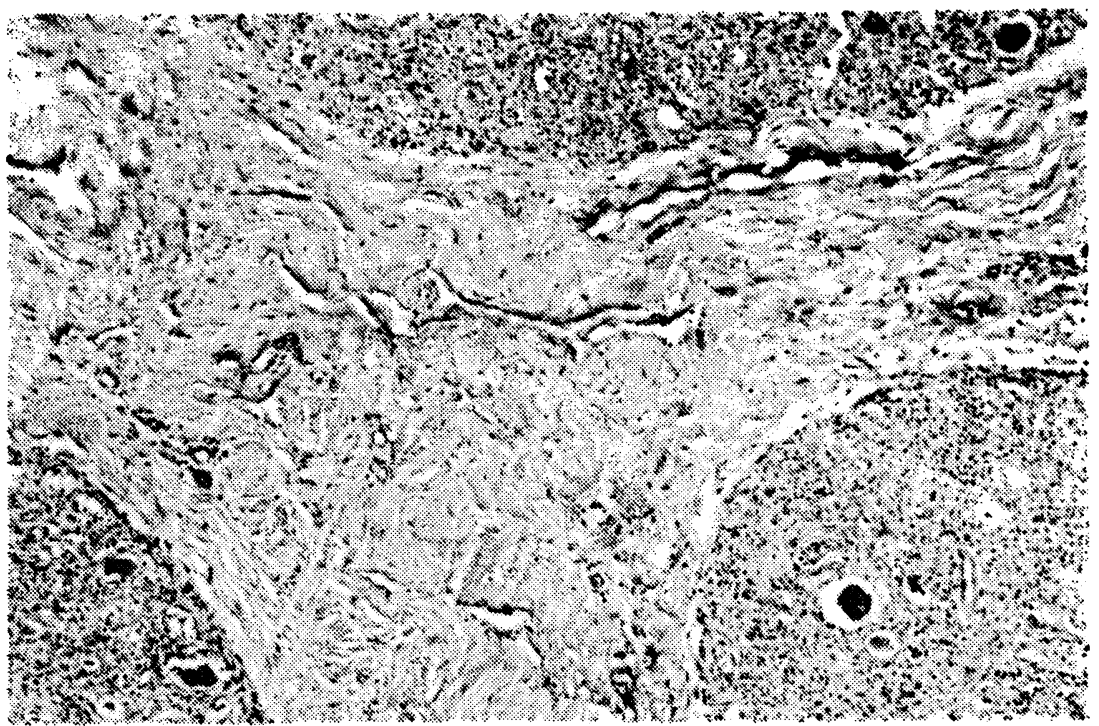

Fig. 4. Fifteen days post-inoculation; marked fibrosis in the infected gland leading to thickening of interlobular septa and replacing the secretory parenchyma. H. E. X 75 .

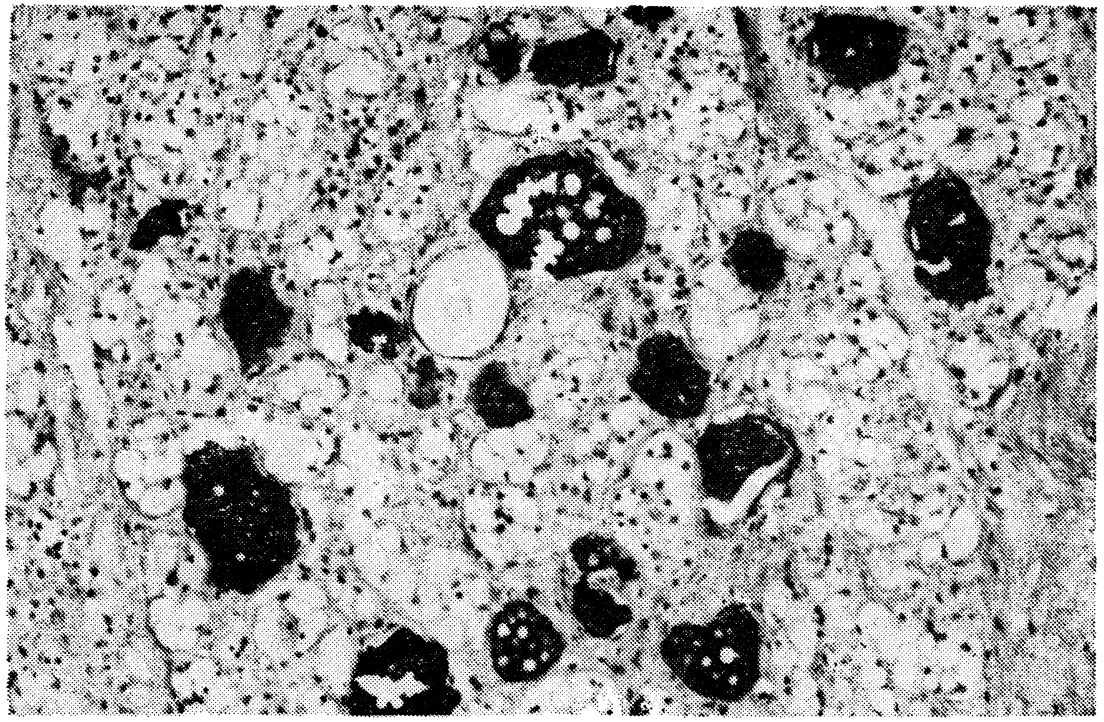

Fig. 5. Increased formation of calcified corpora amylacea in the acini of the same gland as shown in Figs. 4 and 5. H. E. X 150. 


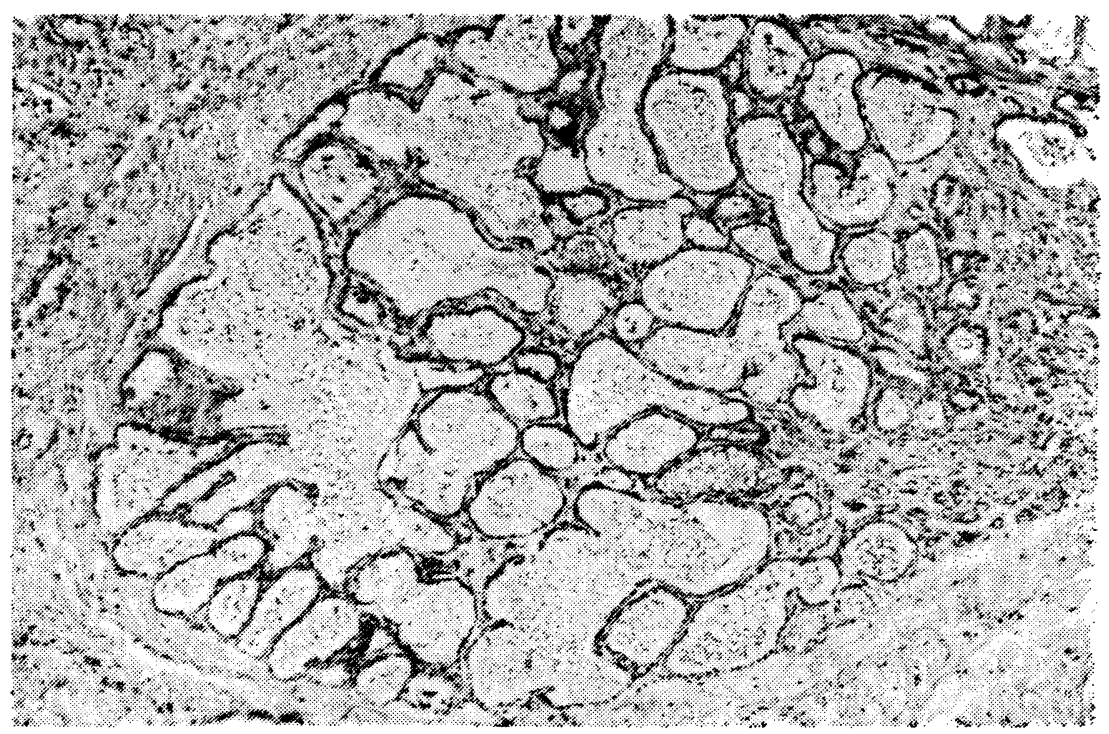

Fig. 6. Twenty days post-inoculation; cystic dilatation of a group of acini surrounded by marked fibrosis in chronic mastitis. H. E. X 75 .

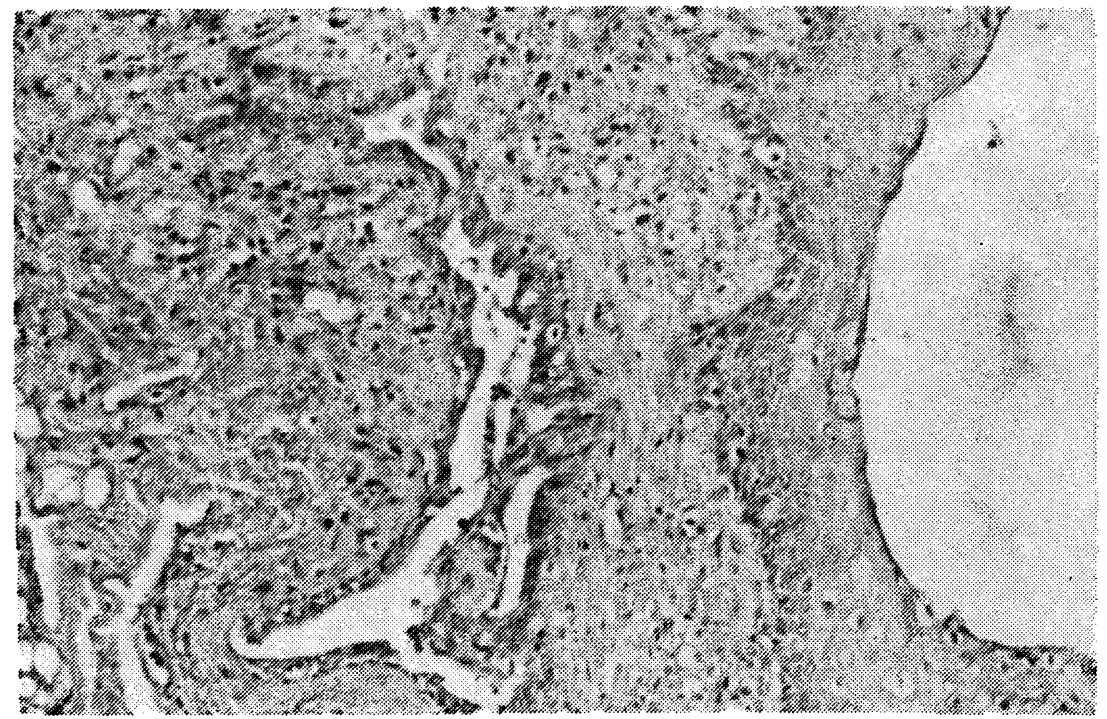

Fig. 7. Thirty five days post-inoculation; stratified squamous metaplasia of the milk duct epithelium in chronic galactophoritis. H. E. X 150. 
goats showed acute to chronic lymphadenitis with marked hyperplasia of lymphoid tissue. No pathological changes were observed in the left control glands and their corresponding lymph nodes.

\section{Discussion}

In the present experimental study, severe clinical mastitis was observed in the infected mammary glands of all the 7 goats from the next day after unilateral intramammary inoculation of $M$. oc The clinical signs produced were confined to the infected glands -only, in contrast to the systemic disease associated with $M$. agalactiae mastitis ( $\mathrm{Jubb}$ et al. 1985). The marked increase in the somatic cell count in the mammary secretions of the infected glands may be due to the chemotactic action exerted on the blood leucocytes by the host inflammatory factors and the causative organisms present in both, the acini and the ducts of the glands as well as by the damaged tissue. A marked reduction in the mammary secretions followed by agalactia was observed in the infected glands. Since $M y c o-$ plasma has special affinity for secretory epithelial surface, it gets firmly attached to the secretory epithelium of acini and causes permanent damage to it by various mechanisms such as increase in local concentration of potent proteolytic enzymes, nucleases and other toxic metabolites such as hydrogen peroxide $\left(\mathrm{H}_{2} \mathrm{O}_{2}\right)$ released by the mycoplasmas (Razin 1978). Mycoplasmas may also cause cell damage by activating host mediators of inflammation. This damage to the secretory epithelium leads to marked decrease in the production of milk and subsequently agalactia develops with further damage to the epithelium.

In the present study, the initial inflammatory response of the caprine mammary gland to the infused $M$. oc culture was characterised by a neutrophil response. This is in contrast to the mixed neutrophil and eosinophil response reported in experimental ureaplasma mastitis in ewes (Kennedy and Ball 1987) and Acholeplasma laidlawii (Buchvarova 1979) and M. bovis (Bennet and Jasper 1978) induced mastitis in cows. However, the findings of initial neutrophil response in the present study is in accordance with the findings of other workers in experimental mycoplasmal mastitis in goats (Prasad et al. 1985; Misri et al. 1988). Reasons for these species differences in response to mycoplasma challenge are not yet apparent. Marked lymphocytic and macrophage infiltration seen after the subsiding of acute mastitis in the present study, have also been reported in experimental mycoplasmal mastitis in goats (Misri et al. 1988), ewes (Banga and Gupta 1988) and cows (Jasper et al. 1987) and in experimental ureaplasmal mastitis in ewes (Kennedy and Ball 1987). These findings suggest that strong cell-mediated immune responses are directed against the invading Mycoplasma. Extensive fibrosis and the subsequent replacement of most of the secretory parenchyma seen from 15 days PI onwards, indicates the repair of the degenerated and atrophied tissue. This indicates that $M$. oc induced damage to the caprine mammary gland is permanent resulting in agalactia.

The observations made in the present study confirm the pathogenicity of $M$. ovine/caprine serogroup 11 for the lactating mammary gland of goat. The severity of mastitis was almost similar to that produced in goats with $M$. bovigenitalium (Pal et al. 1983) and M. arginini (Prasad et al. 1985). However, it was more severe as compared to that produced with $A$. oculi (Sharma et al. 1991) and $A$. laidlawii (Singh et al. 1990) in goats. 


\section{Acknowledgements}

We thank Dr. R. H. Leach, Director, Mycoplasma Reference Facility, Central Public Health Laboratory, National Collection of Type Cultures, London, England for supplying the $M$. ovine/ /caprine serogroup 11 (2-D) culture.

\section{Experimentální mastitida koz vyvolaná zárodkem „Mycoplasma ovis/ /caprae“, sérologická skupina 11}

Sedmi laktujícím kozám byl do pravé poloviny mléčné žlázy strukovým kanálkem inokulován $1 \mathrm{ml}$ suspense Mycoplasma ovis/caprae, sérologická skupina 11, obsahující $6 \times 10^{6} \mathrm{CFU} \cdot \mathrm{ml}^{-1}$ (colony forming units). Infikované mléčné žlázy byly od 1. dne po infekci inokulací horké, měkké, edematózní a bolestivé. Fyzikálni vlastnosti mléka $\mathrm{z}$ těchto žláz byly charakteristicky změněné a počty somatických buněk se zvýšily. Postupně se žlázy zmenšovaly a docházelo $\mathrm{k}$ agalakcii. Experiment trval 35 dnů a v 5 denních intervalech byla zviŕata utrácena. Akutní fáze indukované mastitidy byla charakterizována vakuolací a degenerací sekrečního epitelu s výraznou neutrofilní odpovědí a zmnožením makrofágů. Poté nastoupila chronická intersticiální mastitida s lymfocytární infiltrací, chronickou galactophoritis a rozsáhlou fibrózou vedoucí ke značné redukci parenchymu a pokračující agalakcií. Tato studie potvrzuje patogenitu $M$. ovis/caprae sérologické skupiny 11 pro mléčnou žlázu kozy a je prvnim popisem klinicko-patologických znaků experimentální mastitidy vyvolaté tímto mikroorganismem u koz.

\section{Экспериментальный мастит коз, вызванный зародышем ovis/caprae“, серологическая группа 11 \\ „Mycoplasma}

Седьми лактирующим козам вводили в правую половину молочной железы сосковым канальцем 1 мл суспензии Mucoplasma ovis/caprae, серологическая группа 11, содержащей $6 \times 10^{6} \mathrm{CFU} . \mathrm{M}^{-1}$ (colony forming units]. Инфицированные молочные железы с 1 суток после инфекции инокуляцией были горячие, мягкие, отекшие и болезненные. Физические сбойства полученного из упомянутых желез молока отличались характерными изменениями и численность соматических клеток увеличилась. Желези постепенно уменьшались и наступала агалактия. Эксперимент длился 35 суток и в пятисуточных интервалах животных умерщвляли. Острая фаза индүцированного мастита отличалась вакуоляциен и дегенераиней секреторного элителия с выразительным нейтрофильным ответом и умножением макрофрагов. После этого настүпил хронический интерстициальный мастит с лимфоцитарной инфильтрацией, хроническим галактофоритом и обширным фиброзом, вылившимся в значительную редукцию паренхимы и продолжающуюся агалактию. Данные исследования являются подтверждением патогенности M. ovis/caprae серологической группы 11 для молочной железы коз и являются первым описанием клинико-патологических признаков экспериментального мастита коз, вызванного данным микроорганизмом. 


\section{References}

BANERJEE, M. - SINGH, N. - GUPTA, P. P.: Isolation of mycoplasmas from pneumonic lesions of sheep and goats in India. Zbl. Vet. Med. B, 26, 1979: 689-695.

BANGA, H. S.- GUPTA, P. P.: Pathogenicity of $M$. mycoides subsp. mycoides (LC type) for sheep udder. Aust. Vet. J., 65, 1988: 361-363.

BUCHVAROVA, J. G.: Mycoplasma mastitis in cows. Arch. exper. Vet. med., 33, 1979: 943 to 944.

BENNETT, R. H. - JASPER, D. E.: Bovine mycoplasma mastitis from intramammary inoculation of small number of Mycoplasma bovis. I. Microbiology and pathology. Vet. Microbiol., 2, 1978: $341-355$.

COTTEW, G. S. - LLOYD, L. C.-PARSONSON, I. M. - HORE, D. E.: Isolation of Mycoplasma from vulvovaginitis in sheep. Aust. Vet. J., 50, 1974: 576-577.

JASPER, D. E.-BOOTHBY, J. T.-THOMAS, C. B.: Pathogenesis of bovine mycoplasma mastitis. Israel J. Med. Sci., 23, 1987: 625-627.

JUBB, K. V. F. - KENNEDY, P. C. - PALMER, N.: Pathology of Domestic Animals, Academic Press Inc., Florida, Vol. 3. 1985 pp. 390.

KENNEDY, S. - BALL, H. J.: Pathology of experimental Ureaplasma mastitis in ewes. Vet. Pathol., 24, 1987: 302-307.

MISRI, J.-GUPTA, P. P.-SOOD, N.: Experimental mycoplasmal mastitis in goats. Aust. Vet. J., 65, 1988: 33-35.

PAL, B. C.-SINGH, P. P.-PATHAK, R. C.: Mycoplasma bovigenitalium pathogenicity for caprine udder. Indian J. Comp. Microbiol. Immunol. Infect. Dis., 4, 1983: 262-263.

PRASAD, L. N.-GUPTA, P. P. - SINGH, N.: Isolation of mycoplasmas from goat mastitis. Indian J. Anim. Sci., 54, 1984: 1172-1175.

PRASAD, L. N.-GUPTA, P. P.-SINGH, N.: Experimental Mycoplasma arginini mastitis in goats. Aust. Vet. J., 62, 1985: $341-342$.

RAZIN, S.: The Mycoplasmas. Microbiol. Rev., 42, 1978: 414-470.

SHARMA, C. J.-GUPTA, P. P. - BANGA, H. S.: Pathogenicity of Acholeplasma oculi for the mammary gland of goats. Indian Vet. J., 1991 (In Press).

SINGH, A. - GUPTA, P. P.-BANGA, H. S.: Pathogenicity of Acholeplasma laidlawii for the goat udder. Aust. Vet. J., 67, 1990: 155-156.

TIWANA, J. S. - SINGH, N. - KWATRA, M. S.: Isolation of Mycoplasma and Acholeplasma from vulvovaginitis in goats. Indian J. Comp. Microbiol. Immunol. Infect. Dis., 5, 1984: $17-19$. 